\title{
Mortality prediction in chronic interstitial lung diseases (ILDs): ILD-GAP (gender age physiology) and (the new modified classification) TNMC-ILD-GAP
}

Sameer Bansal, Unnati D. Desai*, Jyotsna M. Joshi

Department of Pulmonary Medicine, T. N. Medical College and BYL Nair Hospital, Mumbai, India

Abstract

English:

Introduction: The interstitial lung disease-gender age physiology (ILD-GAP) model has been proposed on the lines of GAPidiopathic pulmonary fibrosis (IPF) to predict mortality in chronic ILDs, other than IPF. We replaced diffusion capacity of lung for carbon monoxide (DLCO) with the easy to perform 6-minute walk distance (6 MWD) in the ILD-GAP and proposed the new modified classification (TNMC)-ILD-GAP model. Our aim was to demonstrate the usefulness of the TNMC-ILD-GAP as a predictor of mortality in all chronic ILDs and compare the results with the ILD-GAP.

Methods: It was a retrospective observational study conducted at a tertiary care centre. Baseline characteristics of the patients among different ILD groups were analysed. A 3-year follow-up was recorded. The results were compared with the original ILDGAP model. Chi-square and paired t-test was used for comparison of qualitative and quantitative data, respectively.

Results: Mean ages were $62.34( \pm 9.85), 57.9( \pm 11.6), 46.1( \pm 14.6)$ and $55.5( \pm 14.7)$ in IPF, non-specific interstitial pneumonitis (NSIP), connective tissue disease (CTD) and unclassifiable groups, respectively. There were $50 \%, 18 \%, 26 \%$ and $55 \%$ males in the four categories respectively. Mean $6 \mathrm{MWD}$ was $227 \mathrm{~m}, 302 \mathrm{~m}, 342 \mathrm{~m}$, and $332 \mathrm{~m}$. Mean PaO2 was $64 \mathrm{mmHg}, 70 \mathrm{mmHg}$, $75 \mathrm{mmHg}, 69 \mathrm{mmHg}$. Mean forced vital capacity (FVC) (percentage predicted) was 52, 49, 51 and 54. Most of the patients had comorbidities, among which pulmonary hypertension was the most common. Mortality with ILD-GAP model and TNMC-ILD-GAP showed concordant results as the difference in mortality predicted by ILD-GAP and the TNMC-ILD-GAP models was statistically insignificant $(P>0.050)$.

Conclusion: 6 MWD can serve as a reliable replacement for DLCO in the ILD-GAP model, especially in resource limited settings.

Keywords

6-minute walk distance $\cdot$ DLCO $・ I P F$

\section{Prezicerea Mortalității în Bolile Cronice Interstițiale (ILD): ILD-GAP (Gender Age Physiology) și (The New Modified Classification) TNMC-ILD-GAP}

Rezumat

Romanian:

Introducere: Modelul Gender Age Physiology (ILD-GAP) a fost propus pentru GAP-IPF pentru a prezice mortalitatea în bolile interstițiale (ILD) cronice, altele decât fibroza pulmonară idiopatică (IPF). Am înlocuit în cadrul ILD-GAP difuziunea monoxidului de carbon prin membrana alveolo-capilară (DLCO) cu testul de mers de $6 \mathrm{~min}$, (6 MWD) mai ușor de efectuat, și am propus Noua Clasificare Modificată - modelul TNMC-ILD-GAP. Scopul principal a fost cel de a demonstra utilitatea TNMC-ILD-GAP ca predictor al mortalității în toate bolile interstițiale cornice (ILD) și de a compare rezultatele cu cele ale ILD-GAP.

Metode: Am efectuat un studiu restrospectiv observațional condus într-un centru de îngrijiri terțiar. Au fost analizate caracteristicile inițiale ale pacienților cu diferite grupuri de ILD. Am înregistrat evoluția acestora pe durata a 3 ani. Rezultatele au fost comparate cu modelul original ILD-GAP. Pentru compararea datelor calitative și cantitative a fost utilizat Chi-square și respectiv testul t pe perechi.

Rezultate: Vârsta medie a fost de 62.34 ( \pm 9.85$), 57.9$ ( \pm 11.6$), 46.1$ ( \pm 14.6$)$, și 55.5 ( \pm 14.7$)$ în IPF, NSIP, CTD și grupul afecțiunilor neclasificabile. Bărbații au reprezentat 50\%, 18\%, 26\%, și respectiv 55\% în cele patru categorii de boli. Distanța medie la 6 MWD a fost de 227, 302, 342, și respectiv 332 metri. PaO2 medie a fost 64, 70, 75, $69 \mathrm{~mm} \mathrm{Hg}$. FVC medie (procent din prezis) a fost 52, 49, 51 și respectiv 54. Cei mai mulți dintre pacienți aveau comorbidități, cea mai comună fiind hipertensiunea pulmonară. Mortalitatea calculată cu modelul ILD-GAP și TNMC-ILD-GAP a arătat rezultate concordante, diferența dintre cea prezisă de modelul ILD-GAP și de cel TNMC-ILD-GAP nu a fost semnificativă statistic (P>0.050).

Concluzii: 6 MWD poate fi folosit în locul DLCO în modelul ILD-GAP, în special în locațiile cu resurse limitate.

Cuvinte-cheie

testul de mers de $6 \mathrm{~min} \cdot \mathrm{DLCO} \cdot \mathrm{FPI}$

${ }^{*}$ Corresponding author: Unnati Desai

E-mail: unnati_desai82@yahoo.co.in

ว Open Access. ๑ 2021 Joshi et al., published by Sciendo

(G) Br.NC:ND This work is licensed under the Creative Commons Attribution-NonCommercial-NoDerivs 4.0 License. 


\section{Introduction}

Chronic interstitial lung diseases (ILDs) have a wide spectrum, and include idiopathic pulmonary fibrosis (IPF), non-specific interstitial pneumonitis (NSIP), chronic hypersensitivity pneumonitis (HP), connective tissue disease (CTD)-related ILDs and unclassifiable ILDs (1). Survival is not consistent among these different conditions: whereas conditions like IPF have a poor prognosis, other ILDs such as CTD-related ILD have slightly more favourable outcomes (2). Previous risk prediction models in ILD have focused mostly on IPF (3-5), with the gender age physiology (GAP) risk assessment system, now being widely used as a clinical prediction tool for prognostication in IPF. This has led to exclusion of a large number of patients with other forms of chronic ILD.

Recently, however, there has been demonstration of risk assessment in other chronic ILDs. An ILD-GAP model has been postulated, which predicts survival among different ILDs (1). It uses variables such as age, sex, forced vital capacity (FVC) and diffusion capacity of the lungs for carbon monoxide (DLCO), as that used in the original GAP-IPF model. In addition, points have been assigned to the type of ILD, with IPF and unclassifiable ILD carrying 0, and CTDrelated, NSIP and chronic HP carrying 2 points.

Availability of DLCO is questionable at resource limited settings. This is because of the cost of the machine, the cumbersome set-up which involves gas cylinders and their regular refilling, among other reasons. The 6-minute walk distance (6 MWD) test has been found to be of prognostic importance in many studies $(6,7)$, and is also easy to perform. We decided to study the ILD-GAP model replacing DLCO with $6 \mathrm{MWD}$, giving the nomenclature the new modified classification (TNMC)-ILD-GAP, as it represented both the short form and the abbreviated name of our institute.

\section{Materials and methods}

A retrospective observational study was undertaken at a tertiary care centre after permission from the ethical committee. The data is a subset of the ILD India registry. ILD patients aged $>18$ years and with a minimum available follow-up of 3 years were included in the study. Patients with concomitant active infection, including tuberculosis, and those with neoplasm were excluded from the study. These patients presented to the Department of Pulmonary Medicine, Nair Hospital between March 2014 and February 2015. The patients were diagnosed as ILD cases on the basis of clinico-radiological correlation. Classification of ILDs, namely IPF, NSIP, CTD-related ILD and unclassifiable ILD was based on the multidisciplinary approach, including clinical examination and history, radiology as suggested by high-resolution computed tomography (HRCT) pattern, histopathology in the case of open lung biopsy and specialty consultations such as rheumatology in the case of CTDs. The clinical characteristics and comorbidities were noted. All patients were evaluated with spirometry, DLCO, 6 MWD, arterial blood gas (ABG) and two-dimensional echocardiography (2D ECHO). Spirometry and DLCO were performed on MedGraphics ${ }^{\circledR}$ Cardiopulmonary Diagnostic System. ILD-GAP index and TNMC-ILD-GAP index was calculated for all patients at baseline (Table 1). This was done by replacing DLCO in the ILD-GAP index with 6 MWD. As no previous data on severity classification of 6 MWD was available in ILD, we applied the classification of 6 MWD as per BODE index, validated and used in COPD (8). DLCO grading in ILD-GAP and 6 MWD grading as per BODE index (8) both consists of scores 0, 1, 2 and 3 .

Patients were followed up at 3-month intervals. The 3-month follow-ups included clinical evaluation, 6 MWT, ABG and a spirometry with DLCO. Annual HRCT thorax and a 2D ECHO were done for the patients. In the case of mortality, time, place and cause of mortality were taken into account. The patients were categorised as ILD-GAP and TNMC-ILD-GAP classes I, II, II and IV, depending on their baseline scores of $0-1,2-3$, $4-5$, and $>5$ respectively. For each of these four stages (i.e. I, II, III and IV), 1st year, 2nd year and 3rd year mortality was noted. The mortality rates were therefore calculated for all four ILD groups using this method. The calculated mortality rates were then compared with the originally predicted mortality rates using the ILD-GAP index. Significance in the differences, if any, was noted. The mortality rates calculated using both the indices were also compared with each other for any statistical significance. Each of the independent variables, such as 6 MWD, DLCO, pulmonary hypertension and FVC\%, were also assessed for any significance in mortality prediction. Correlation between these statistically significant parameters was also measured.

Descriptive statistics including frequencies and percentages as well as mean and standard deviation for continuous variables were calculated. Chi-squared testing was performed to assess whether the comorbidities were a significant predictor of mortality. Linear regression was applied to check for any correlation between variables. Paired $t$-test was used to compare the mortalities as calculated using ILD-GAP and the TNMC-ILD-GAP indices. $P$-value 0.050 was considered as statistically significant.

\section{Results}

A total of 120 patients including 70 IPF, 22 NSIP, 19 CTDrelated and 9 unclassifiable ILD patients were enrolled. Of 
Table 1. ILD-GAP index and TNMC-ILD-GAP index

\begin{tabular}{llc}
\hline ILD-GAP index & & \\
\hline \multirow{2}{*}{ Gender } & Parameters & Points \\
& Female & 0 \\
Age & Male & 1 \\
& $<60$ & 0 \\
FVC & $61-65$ & 1 \\
& $>65$ & 2 \\
& $>75 \%$ & 0 \\
DLCO & $50-75 \%$ & 1 \\
& $<50 \%$ & 2 \\
& $>55$ & 0 \\
& $36-55$ & 1 \\
& $<35$ & 2 \\
Type of ILD & Unable to perform & 3 \\
& IPF & 0 \\
& Unclassifiable & 0 \\
& NSIP & -2 \\
\hline
\end{tabular}

\begin{tabular}{llc}
\hline TNMC-ILD-GAP index & & \\
\hline \multirow{2}{*}{ Gender } & Parameters & Points \\
& Female & 0 \\
Age & Male & 1 \\
& $<60$ & 0 \\
& $61-65$ & 1 \\
FVC & $>65$ & 2 \\
& $>75 \%$ & 0 \\
6 MWD & $50-75 \%$ & 1 \\
& $<50 \%$ & 2 \\
& $>350 \mathrm{~m}$ & 0 \\
& $250-349$ & 1 \\
& $150-249$ & 2 \\
Type of ILD & $<150$ & 3 \\
& IPF & 0 \\
& Unclassifiable & 0 \\
& NSIP & -2 \\
& CTD-related ILD & -2 \\
\hline
\end{tabular}

\begin{tabular}{lccc}
\hline \multicolumn{3}{c}{ Mortality in ILD-GAP model (\%) } \\
\hline & 1 year & 2 years & 3 years \\
\hline $0-1$ & 3 & 6 & 10 \\
$2-3$ & 8.80 & 18.00 & 27 \\
$4-5$ & 18 & 35 & 49 \\
$>5$ & 33.50 & 58.40 & 74.80 \\
\hline
\end{tabular}

CTD, connective tissue disease; DLCO, diffusion capacity of lung for carbon monoxide; FVC, forced vital capacity; GAP, gender age physiology; IPF, idiopathic pulmonary fibrosis; ILD, interstitial lung disease; MWD, minute walk distance; NSIP, non-specific interstitial pneumonitis; TNMC, the new modified classification. these 120 patients, 109 were diagnosed with the help of clinic-radiological correlation, while 11 patients required an open lung biopsy for the diagnosis. There were $35(50 \%)$, $4(18 \%), 5(26 \%)$ and $5(55 \%)$ men in these four groups, respectively. The mean age among these four categories was 62.3 ( \pm 9.8$), 57.9( \pm 11.6), 46.1( \pm 14.5)$ and $55.5( \pm 14.7)$. The average duration of symptoms was $2.8( \pm 2.4)$ in IPF, $4.2( \pm 4.1)$ in NSIP, $5.1( \pm 10.2)$ in the CTD-ILD group and $2.6( \pm 2.8)$ years in the unclassifiable ILD group. Cough and dyspnea were present in almost all the patients $(97.1 \%)$. Among the four different groups, 31.5\%, 9\%, 5\% and $44.4 \%$ patients were smokers; clubbing was present in 69 patients (57.5\%); and almost all had the presence of crackles on respiratory system examination. The mean 6 MWD was 227 $( \pm 98.5) \mathrm{m}, 302( \pm 106) \mathrm{m}, 343( \pm 67.2) \mathrm{m}$, and $332( \pm 138.7) \mathrm{m}$ in the four categories, respectively. The mean $\mathrm{PaO} 2$ on $\mathrm{ABG}$ was $64.2 \mathrm{mmHg}, 70.5 \mathrm{mmHg}, 75 \mathrm{mmHg}$ and $69 \mathrm{mmHg}$, respectively. Mean FVC (percentage predicted) was $51.9 \%$ $( \pm 17.3), 49.5 \%( \pm 16.2), 50.9 \%( \pm 11.2)$ and $53.7 \%( \pm 17.3)$, respectively. Mean DLCO was $44.5( \pm 24.1) \mathrm{mmol}, 47.4$ $( \pm 26.2) \mathrm{mmol}, 42.3( \pm 26.5) \mathrm{mmol}$ and $40.6( \pm 20.7) \mathrm{mmol}$ $\mathrm{CO} / \mathrm{min} / \mathrm{kPa}$, respectively, in the four groups of patients. It was interestingly noted that $45(64 \%), 10(45.5 \%), 4$ $(21 \%)$ and $1(11 \%)$ patients in each of the four categories could not perform DLCO satisfactorily. Of the 19 patients in the CTD-related ILD group, 8 had rheumatoid arthritis (RA), 5 had scleroderma, 5 had mixed connective tissue disorder (MCTD) and 1 had systemic lupus erythomatosis (SLE). Table 2 demonstrates the baseline characteristics among the four different ILD groups. The most common comorbidities included gastro-esophageal reflux disease (45\%), hypertension (31\%), diabetes mellitus $(28 \%)$ and osteoporosis (25\%). Pulmonary hypertension was observed in almost all patients, of which $42(35 \%)$ had moderate to severe pulmonary hypertension (pulmonary artery systolic pressure calculated by indirect estimation of tricuspid regurgitation jet $>40 \mathrm{mmHg}$ ).

The mean ILD-GAP index was $6( \pm 2)$ for IPF, $3( \pm 1)$ for NSIP, $2( \pm 1)$ for CTD-ILD and $4( \pm 1)$ for unclassifiable group patients. The mean TNMC-GAP-ILD was $6( \pm 2), 2( \pm 1), 1$ $( \pm 1)$ and $3( \pm 1)$ for the four groups of patients, respectively. With ILD-GAP application, 24 patients fell in stage I (score $0-1), 28$ in stage II (2-3), 32 in stage III (4-5), and 36 in stage IV $( \pm 5)$. In all, 25 of the $32(78 \%)$ patients in stage III, and 34 of the 36 patients (94\%) in stage IV were in the IPF group, suggesting poorer prognosis in these patients. With TNMC-ILD-GAP application, $32(26.7 \%)$ patients fell in stage I, $30(25 \%)$ in stage II, $27(22.5 \%)$ in stage III, and $31(25.8 \%)$ in stage IV. As seen with ILD-GAP, the majority of patients in stages III and IV belonged to the IPF group ( $89 \%$ and $97 \%$ respectively). With both the indices, stage I patients constituted mainly of the CTD-ILD and NSIP groups. 
Table 2. Baseline characteristics among four different ILD groups

\begin{tabular}{|c|c|c|c|c|}
\hline & & Type of ILD & & \\
\hline Baseline characteristics & IPF & NSIP & CTD & Unclassifiable \\
\hline Mean (SD) & $(n=70)$ & $(n=22)$ & $(n=19)$ & $(n=9)$ \\
\hline Age (years) & $62.34(9.85)$ & $57.9(11.6)$ & $46.1(14.6)$ & $55.5(14.7)$ \\
\hline Males - n (\%) & $35(50)$ & $4(18)$ & $5(26)$ & $5(55.5)$ \\
\hline Smokers - n (\%) & $22(31.5)$ & $2(9)$ & $1(5)$ & $4(44.4)$ \\
\hline $\mathrm{PaO} 2(\mathrm{mmHg})$ & $64.2(12.5)$ & $70(12.6)$ & $75.4(11.5)$ & $69.25(13.5)$ \\
\hline $6 \mathrm{MWD}(\mathrm{m})$ & $227.3(98.56)$ & $302(106)$ & $342(67.2)$ & $332.7(138.7)$ \\
\hline $\mathrm{FVC}(\mathrm{L})$ & $1.414(0.694)$ & $1.27(0.45)$ & $1.45(0.42)$ & $1.64(0.67)$ \\
\hline FVC (\% predicted) & $51.91(17.3)$ & $49.5(16.2)$ & $50.9(11.2)$ & $53.7(17.3)$ \\
\hline
\end{tabular}

CTD, connective tissue disease; FVC, forced vital capacity; IPF, idiopathic pulmonary fibrosis; ILD, interstitial lung disease; MWD, minute walk distance;

NSIP, non-specific interstitial pneumonitis.

Table 3. Comparison between mortality rates in the original ILDGAP model and in our study group

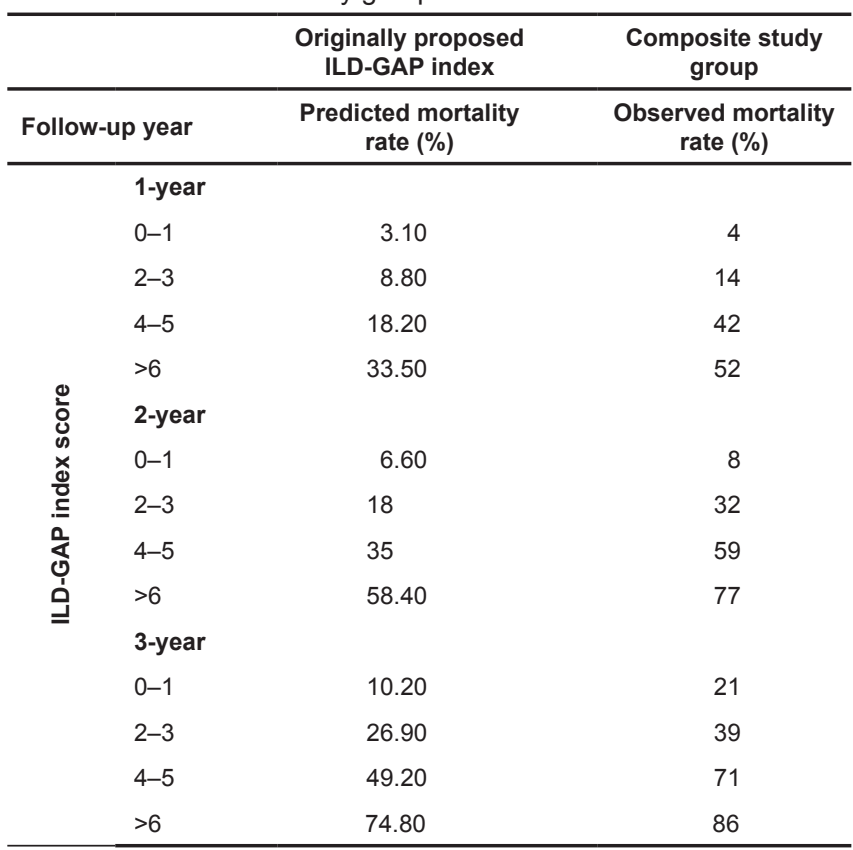

GAP, gender age physiology; ILD, interstitial lung disease.

A total of 70 patients died at the end of 3 years -50 in IPF, 10 in NSIP, 4 among CTD-ILD and 6 in the unclassifiable ILD group. Mortality was the least in the CTD-ILD group (21\%), worse in NSIP (45\%), and worst with IPF and unclassifiable ILDs $(71 \%$ and $66 \%$, respectively). None of the patients fell into groups 3 or 4 in CTD-related ILD, and only 1 patient each in NSIP and unclassifiable ILD group had an ILD/TNMC-ILD GAP index of $>5$. These patients were therefore excluded from the results to prevent confounding. Table 3 shows the comparative mortalities predicted by the original ILD-GAP model and those observed in our study group. We observed higher 1-, 2- and 3-year mortality rates in our cohort. Tables 4 and 5 show the division of patients in the four stages of ILD-
Table 4. Composition and mortality rates of different ILD groups based on ILD-GAP index staging

\begin{tabular}{|c|c|c|c|c|}
\hline \multirow{2}{*}{ ILD-GAP stage } & \multirow{2}{*}{ Total patients $(n)$} & \multicolumn{3}{|c|}{ Mortality - $n(\%)$} \\
\hline & & 1st year & 2nd year & 3rd year \\
\hline \multicolumn{5}{|l|}{ IPF } \\
\hline 1 & 3 & $0(0)$ & $0(0)$ & $1(33)$ \\
\hline II & 8 & $2(25)$ & $1(37.5)$ & $0(38)$ \\
\hline III & 25 & $11(44)$ & $2(52)$ & $3(64)$ \\
\hline IV & 34 & $18(53)$ & $9(79.5)$ & $3(88.2)$ \\
\hline \multicolumn{5}{|l|}{ NSIP } \\
\hline 1 & 11 & $1(9)$ & $1(18)$ & $2(36)$ \\
\hline II & 8 & $1(12.5)$ & $2(37.5)$ & $1(50)$ \\
\hline III & 2 & $1(50)$ & $1(100)$ & $0(100)$ \\
\hline IV & 1 & 0 & 0 & 0 \\
\hline \multicolumn{5}{|l|}{ CTD-related ILD } \\
\hline I & 9 & 0 & 0 & 0 \\
\hline II & 10 & $1(10)$ & $2(30)$ & $1(40)$ \\
\hline III & 0 & 0 & 0 & 0 \\
\hline IV & 0 & 0 & 0 & 0 \\
\hline \multicolumn{5}{|c|}{ Unclassifiable ILDs } \\
\hline 1 & 1 & 0 & 0 & 0 \\
\hline II & 2 & 0 & 0 & 0 \\
\hline III & 5 & $1(20)$ & $3(80)$ & $1(100)$ \\
\hline IV & 1 & $1(100)$ & $0(100)$ & $0(100)$ \\
\hline \multicolumn{5}{|c|}{ Composite study group } \\
\hline I & 24 & $1(4)$ & $1(8.3)$ & $3(20.8)$ \\
\hline II & 28 & $4(14.3)$ & $5(32)$ & $2(39.2)$ \\
\hline III & 32 & $13(40.6)$ & $6(59)$ & $4(71.2)$ \\
\hline IV & 36 & $19(52.7)$ & $9(77.7)$ & $3(86.1)$ \\
\hline
\end{tabular}

CTD, connective tissue disease; GAP, gender age physiology; IPF, idiopathic pulmonary fibrosis; ILD, interstitial lung disease; NSIP, non-specific interstitial pneumonitis.

GAP and TNMC-ILD GAP index in the four different types of ILDs. Table 6 shows the predicted mortality rates when ILD-GAP index and TNMC-ILD-GAP indices were applied. 
Table 5. Composition and mortality rates of different ILD groups based on TNMC-ILD-GAP index staging

\begin{tabular}{|c|c|c|c|c|}
\hline \multirow{2}{*}{$\begin{array}{l}\text { TNMC-ILD-GAP } \\
\text { stage }\end{array}$} & \multirow{2}{*}{ Total patients $(n)$} & \multicolumn{3}{|c|}{ Mortality $-n(\%)$} \\
\hline & & 1st year & 2nd year & 3rd year \\
\hline \multicolumn{5}{|l|}{ IPF } \\
\hline I & 7 & $1(14)$ & $0(14)$ & $2(43)$ \\
\hline ॥ & 9 & $2(22.2)$ & $1(33.33)$ & $0(33)$ \\
\hline III & 24 & $10(42)$ & $5(63)$ & $2(71)$ \\
\hline IV & 30 & $18(60)$ & $6(80)$ & $3(90)$ \\
\hline \multicolumn{5}{|l|}{ NSIP } \\
\hline I & 9 & 0 & 0 & $2(22)$ \\
\hline II & 13 & $3(23)$ & $4(54)$ & $1(62)$ \\
\hline III & 0 & 0 & 0 & 0 \\
\hline IV & 0 & 0 & 0 & 0 \\
\hline \multicolumn{5}{|l|}{ CTD-related ILD } \\
\hline I & 15 & 0 & $1(7)$ & $1(13)$ \\
\hline II & 4 & $1(25)$ & $1(50)$ & $0(50)$ \\
\hline III & 0 & 0 & 0 & 0 \\
\hline IV & 0 & 0 & 0 & 0 \\
\hline \multicolumn{5}{|c|}{ Unclassifiable ILDs } \\
\hline I & 1 & 0 & 0 & 0 \\
\hline ॥ & 4 & 0 & $1(25)$ & $1(50)$ \\
\hline III & 3 & $1(33)$ & $2(100)$ & $0(100)$ \\
\hline IV & 1 & $1(100)$ & $0(100)$ & $0(100)$ \\
\hline \multicolumn{5}{|c|}{ Composite study group } \\
\hline 1 & 32 & $1(3)$ & $1(6.2)$ & $5(21.8)$ \\
\hline II & 30 & $6(20)$ & $7(43)$ & $2(50)$ \\
\hline III & 27 & $11(40.7)$ & $7(66.67)$ & $2(74)$ \\
\hline IV & 31 & $19(61.2)$ & $6(80.6)$ & $3(90)$ \\
\hline
\end{tabular}

CTD, connective tissue disease; GAP, gender age physiology; IPF, idiopathic pulmonary fibrosis; ILD, interstitial lung disease; NSIP, non-specific interstitia pneumonitis; TNMC, the new modified classification.

The mortality rates were comparable as the difference in mortality predicted by ILD-GAP and the TNMC-ILD-GAP models was statistically insignificant $(P>0.050)$.

Independent factor analysis confirmed the significance of parameters of ILD-GAP and TNMC-GAP-ILD. Gender, age, grade of restriction (FVC $<50 \%$ ), DLCO and $6 \mathrm{MWD}$ were the most significant parameters affecting survival. $63 \%$ of the male patients and $55 \%$ of the female patients died at the end of 3 years. Mortality also increased as age progressed. Of the 52 patients aged $>65$ years, 36 died at the end of 3 years $(P<0.050)$. Severe restriction (FVC $<50 \%$ ) was present in $35(50 \%), 13(59 \%), 10(52 \%)$ and $4(44 \%)$ patients respectively. Of the 64 patients, 48 had severe restrictions and died by the end of the 3-year follow-up $(P<0.050)$. A total of 83 patients had a DLCO $<35$ or could not perform DLCO. Of these, 54 patients died at the end of 3 years $(P<0.050)$. Eighty-five patients
(70.8\%) had 6 MWD $<350 \mathrm{~m} ; 60$ of these patients $(70 \%)$ died at the end of 3 years $(P<0.050)$. Of the 61 patients with $6 \mathrm{MWD}<250 \mathrm{~m}, 47(77 \%)$ died at the end of 3 years $(P<0.050)$ and 19 of the 20 patients $(95 \%)$ with 6 MWD $<150 \mathrm{~m}$ died at the end of 3 years $(P<0.050)$. It was hence seen that mortality increased as the 6 MWD decreased, and this was statistically significant (Table 7 ).

$6 \mathrm{MWD}$ also had good correlation with these other parameters that formed a part of the ILD-GAP index, namely FVC\% predicted and DLCO\% predicted (Table 8). Pearson's correlation coefficient $(r)$ between FVC and 6 MWD, and DLCO and 6 MWD was 0.43 and 0.27 , respectively, and this was statistically significant, with $P$-value being $<0.001$ and $<0.05$, respectively (Figures 1 and 2). Furthermore, $6 \mathrm{MWD}$ also correlated significantly with $\mathrm{PaO} 2$, with the correlation coefficient $(r)$ being $0.56(P<0.001)$ (Figure 3$)$.

\section{Discussion}

ILDs are a group of diffuse parenchymal lung disorders associated with substantial morbidity and mortality. According to the current international guidelines the idiopathic interstitial pneumonias (IIPs) are grouped into three categories: major, rare and unclassifiable (9). IPF is one of the major IIPs and has been recognised as a distinct clinical entity since 2001 . While multidisciplinary team assessment yields a definite diagnosis in many cases of ILD, $15-25 \%$ of patients remain unclassifiable (10).

Chronic ILDs are progressive ILDs wherein heterogeneities in clinical course and survival times have been noted (11). With limited effective medical therapies and lung transplantation facilities, counselling of patients about the life expectancy, monitoring for disease progression and discussing end-of-life care was the felt need. Staging systems/severity assessment has been in use in asthma, COPD and lung cancer (12-14). However, there was a deficiency of such a definitive robust system in ILD. Previous risk prediction models in ILD have focused mainly on IPF, thereby excluding a large number of patients with other forms of chronic ILD. GAP-IPF model was first proposed in 2012 by Ley et al in 2012, based on gender, age and physiology variables. They reported a mortality of $6 \%, 11 \%, 16 \%$ in GAP I, $16 \%, 30 \%$ and $42 \%$ in GAP II, and $39 \%, 62 \%$ and $77 \%$ in GAP III, at the end of 1 year, 2 years and 3 years, respectively. Various geographic regions reported varied correlation with the original GAP-IPF staging system. However, GAP-IPF excluded a large number of patients with other forms of chronic ILD. Previous studies have noted the chronic ILD subgroups as IPF, NSIP and CTDILD combined, chronic HP and unclassifiable ILD. Reyersen et al. had 326, 307, 206 and 173 patients, respectively, in these four categories (1). Su-Ying Low had 44 patients, of 
Table 6. Comparison between ILD GAP mortality and TNMC-GAP ILD mortality in our cohort (Blank entries in the table represent conditions that were met by too few patients/no patients to perform analyses)

\begin{tabular}{|c|c|c|c|c|c|c|c|c|c|c|c|c|c|}
\hline \multirow{2}{*}{\multicolumn{2}{|c|}{$\begin{array}{l}\text { Type of ILD } \\
\text { Predicted } \\
\text { mortality }\end{array}$}} & \multicolumn{3}{|c|}{ IPF } & \multicolumn{3}{|c|}{ NSIP } & \multicolumn{3}{|c|}{ CTD-ILD } & \multicolumn{3}{|c|}{ Unclassifiable ILD } \\
\hline & & $\begin{array}{l}\text { ILD } \\
\text { GAP } \\
(\%)\end{array}$ & $\begin{array}{l}\text { TNMC- } \\
\text { GAP } \\
\text { ILD (\%) }\end{array}$ & $P$-value & $\begin{array}{l}\text { ILD } \\
\text { GAP } \\
(\%)\end{array}$ & $\begin{array}{l}\text { TNMC- } \\
\text { GAP } \\
\text { ILD (\%) }\end{array}$ & $P$-value & $\begin{array}{l}\text { ILD } \\
\text { GAP } \\
(\%)\end{array}$ & $\begin{array}{l}\text { TNMC- } \\
\text { GAP } \\
\text { ILD (\%) }\end{array}$ & $P$-value & $\begin{array}{l}\text { ILD } \\
\text { GAP } \\
(\%)\end{array}$ & $\begin{array}{l}\text { TNMC- } \\
\text { GAP } \\
\text { ILD (\%) }\end{array}$ & $P$-value \\
\hline \multirow{15}{*}{ 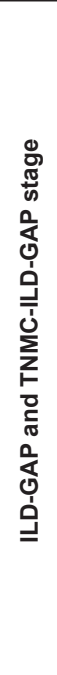 } & \multicolumn{13}{|c|}{ 1st year } \\
\hline & 1 & 0 & 14 & n.s. & 9 & 0 & n.s. & 0 & 0 & n.s. & 0 & 0 & n.s. \\
\hline & II & 25.00 & 22.20 & n.s. & 12.50 & 23.00 & n.s. & 10.00 & 25.00 & n.s. & 0.00 & 0.00 & n.s. \\
\hline & III & 44 & 42 & n.s. & 50 & & & & & & 20 & 33 & n.s. \\
\hline & IV & 53 & 60 & n.s. & & & & & & & 100 & 100 & n.s. \\
\hline & \multicolumn{13}{|c|}{ 2nd year } \\
\hline & 1 & 0 & 14 & n.s. & 18 & 7 & n.s. & 0 & 7 & n.s. & 0 & 0 & n.s. \\
\hline & II & 37.50 & 33.30 & n.s. & 37.50 & 54.00 & n.s. & 30.00 & 50.00 & n.s. & 0.00 & 25.00 & n.s. \\
\hline & III & 52 & 63 & n.s. & 100 & & & & & & 80 & 100 & n.s. \\
\hline & III & 79.40 & 80 & n.s. & & & & & & & 100.00 & 100 & n.s. \\
\hline & \multicolumn{13}{|c|}{ 3rd year } \\
\hline & 1 & 33 & 43 & n.s. & 36 & 22 & n.s. & 7 & 13 & n.s. & 0 & 0 & n.s. \\
\hline & II & 38 & 33 & n.s. & 50 & 62 & n.s. & 50.00 & 50 & n.s. & 0 & 50 & n.s. \\
\hline & III & 64 & 71 & n.s. & 100 & & & & & & 100 & 100 & n.s. \\
\hline & IV & 88.20 & 90 & n.s. & & & & & & & 100.00 & 100 & n.s. \\
\hline
\end{tabular}

CTD, connective tissue disease; GAP, gender age physiology; IPF, idiopathic pulmonary fibrosis; ILD, interstitial lung disease; NSIP, non-specific interstitial pneumonitis; TNMC, the new modified classification; n.s. = not significant.

Table 7. 6 MWD and its significance in mortality

\begin{tabular}{lccc}
\hline & Dead & Alive & $P$-value \\
\hline 6 MWD & 60 & 25 & $<0.001$ \\
$<350 \mathrm{~m}$ & 47 & 14 & $<0.001$ \\
$<250 \mathrm{~m}$ & 19 & 1 & $<0.001$ \\
$<150 \mathrm{~m}$ & 36 & 52 & $<0.050$ \\
Age $>65$ years & 48 & 64 & $<0.050$ \\
FVC $<50 \%$ predicted & 54 & 83 & $<0.050$ \\
DLCO $<35 \%$ predicted & & & \\
\hline
\end{tabular}

DLCO, diffusion capacity of lung for carbon monoxide; FVC, forced vital capacity; MWD, minute walk distance.

whom, 9 had IPF, 15 had NSIP, 16 had CTD-ILD and 2 had unclassifiable ILD (15). Compared to our study, which had a majority of IPF patients (58\%), these studies had less or equal distribution of the IPF and non-IPF patients. This also denotes a different geographical trend of chronic ILDs in our region (Western India).

The recent development of the ILD-GAP model by Ryerson et al. could help determine mortality in non-IPF patients. The ILD-GAP model has been shown to accurately predict mortality in major chronic ILD subtypes and at all stages of disease. The ILD-GAP model was slightly more accurate in non-IPF ILDs than in IPF. This was believed to be because of the more homogeneous natural history of most non-IPF ILDs, compared with the multiple patterns of progression that are
Table 8. Correlation between 6 MWD and other variables

\begin{tabular}{lccc}
\hline \multicolumn{4}{l}{ Correlation between variable } \\
\hline Variable 1 & Variable 2 & Pearson's correlation coefficient $(\boldsymbol{r})$ & $P$-value \\
\hline $\mathrm{FVC}$ & $6 \mathrm{MWD}$ & 0.434372514 & $<0.001$ \\
$\mathrm{PaO}_{2}$ & $6 \mathrm{MWD}$ & 0.567937386 & $<0.001$ \\
$\mathrm{DLCO}$ & $6 \mathrm{MWD}$ & 0.257845773 & $<0.050$ \\
\hline
\end{tabular}

DLCO, diffusion capacity of lung for carbon monoxide; FVC, forced vital capacity; MWD, minute walk distance.

observed in IPF. The GAP and ILD-GAP models could help clinicians more accurately counsel patients with IPF and nonIPF ILDs. The ILD-GAP model proposed by Ryerson et al. divided patients into four stages, with mortality of $3 \%, 6 \%$, $10 \%$ in stage I; $9 \%, 18 \%$ and $27 \%$ in stage II, $18 \%, 35 \%$ and $49 \%$ in stage III, and $33.5 \%, 58 \%$ and $75 \%$ in stage IV, at the end of 1 year, 2 years and 3 years, respectively. A study done by Su-Ying Low in Singapore found that mortalities were higher at each ILD-GAP index than the predicted 3.1\%, 8.8\% and $18.2 \%$ for 1 -year mortality, and $6.6 \%, 18 \%$ and $35 \%$ for 2-year mortality (15). On application of the ILD-GAP model to our patients, we observed overall higher mortality compared to the original study (1). This could be explained due to a higher number of IPF patients (58\%) in our study against only $32 \%$ IPF in the original study by Ryerson et al. There is no literature available on the performance of the ILD-GAP index in the Indian scenario. This is the first study of ILD-GAP 


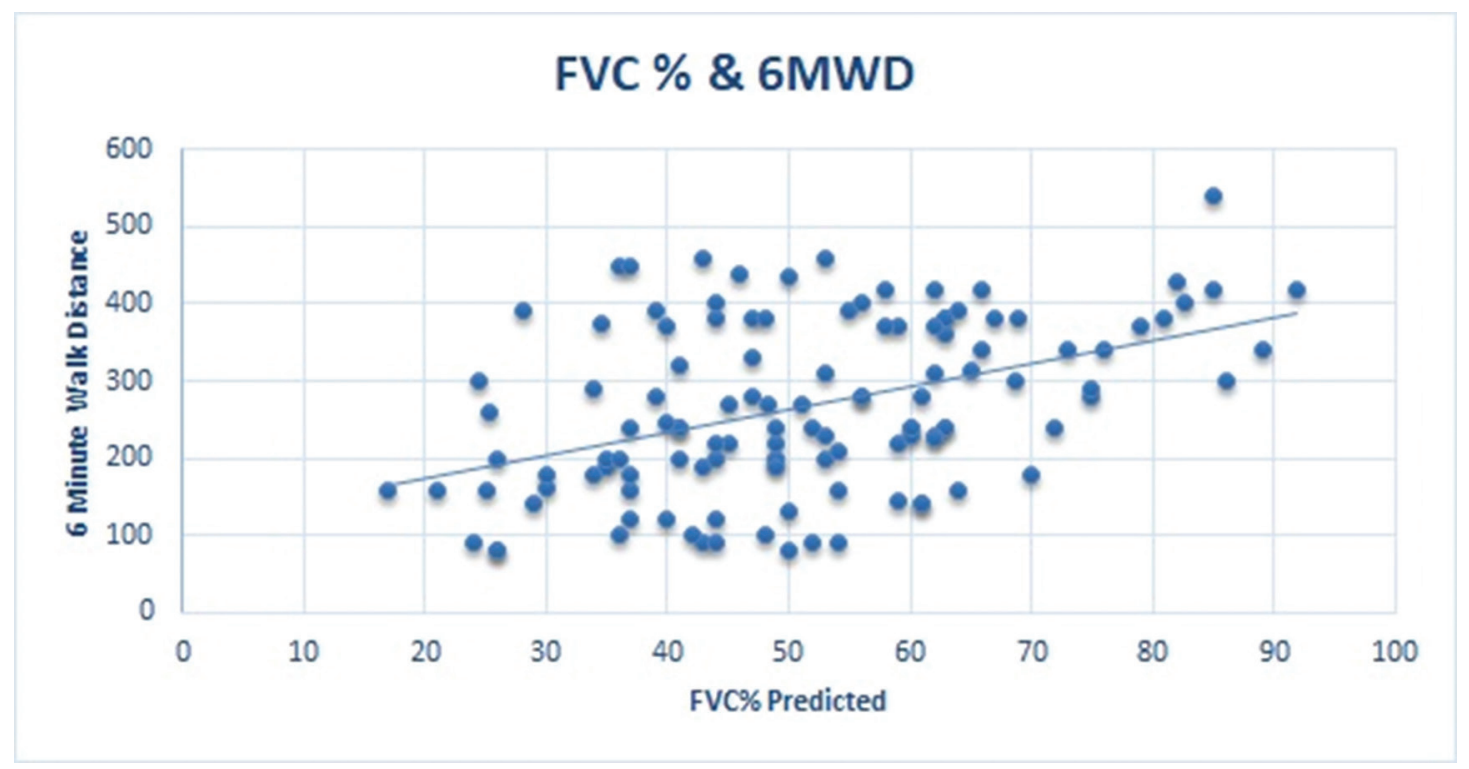

Figure 1. Correlation between 6 MWD and FVC\% Predicted. FVC, forced vital capacity; MWD, minute walk distance.

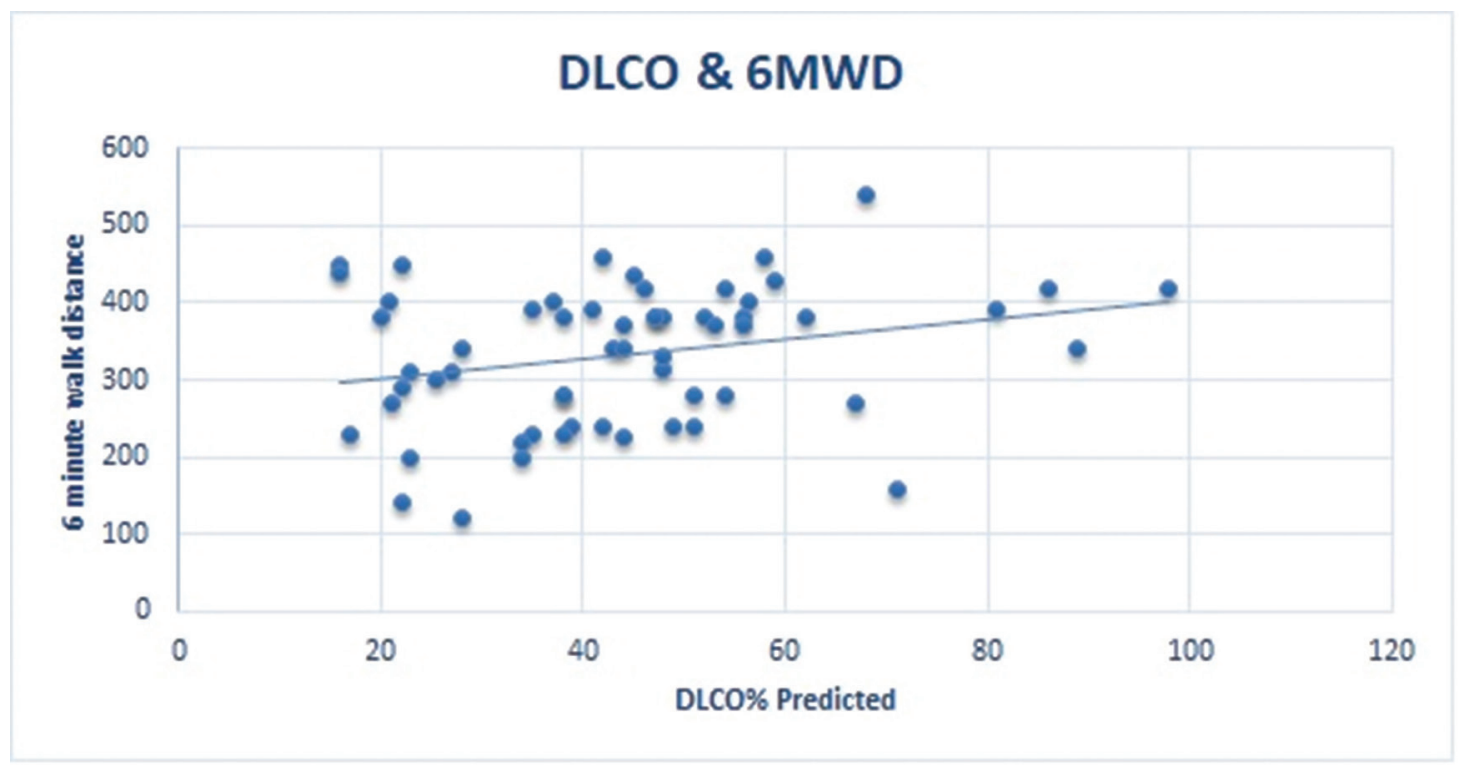

Figure 2. Correlation between $6 \mathrm{MWD}$ and DLCO\% Predicted. DLCO, diffusion capacity of lung for carbon monoxide; MWD, minute walk distance.

application to Indian ILD patients carried out at a tertiary care centre.

DLCO is an important parameter of ILD-GAP (16). DLCO measurement requires a high-end spirometry machine, availability of gases, expert and trained technician to perform the test and breath-hold of at least $10 \mathrm{~s}(17,18)$. These criteria are difficult to meet and resource-consuming even in the most advanced centres. $6 \mathrm{MWD}$ has been found to be of prognostic importance in many studies $(6,7)$. Some studies have found it to be a better prognostic indicator than FVC (19). It can also be used as a reliable follow-up test for objective assessment. DLCO grading in GAP and 6 MWD grading as per BODE index (8) validated in COPD both consist of scores $0,1,2$ and 3. There are no separate cut off/stages of 6 MWD in ILD available in the literature. Substitution of 6 MWD (grading as used in the BODE index) for DLCO did not affect the original scores and staging. Thus, we proposed the TNMC-ILDGAP index. We labelled the index as TNMC-ILD-GAP as it 


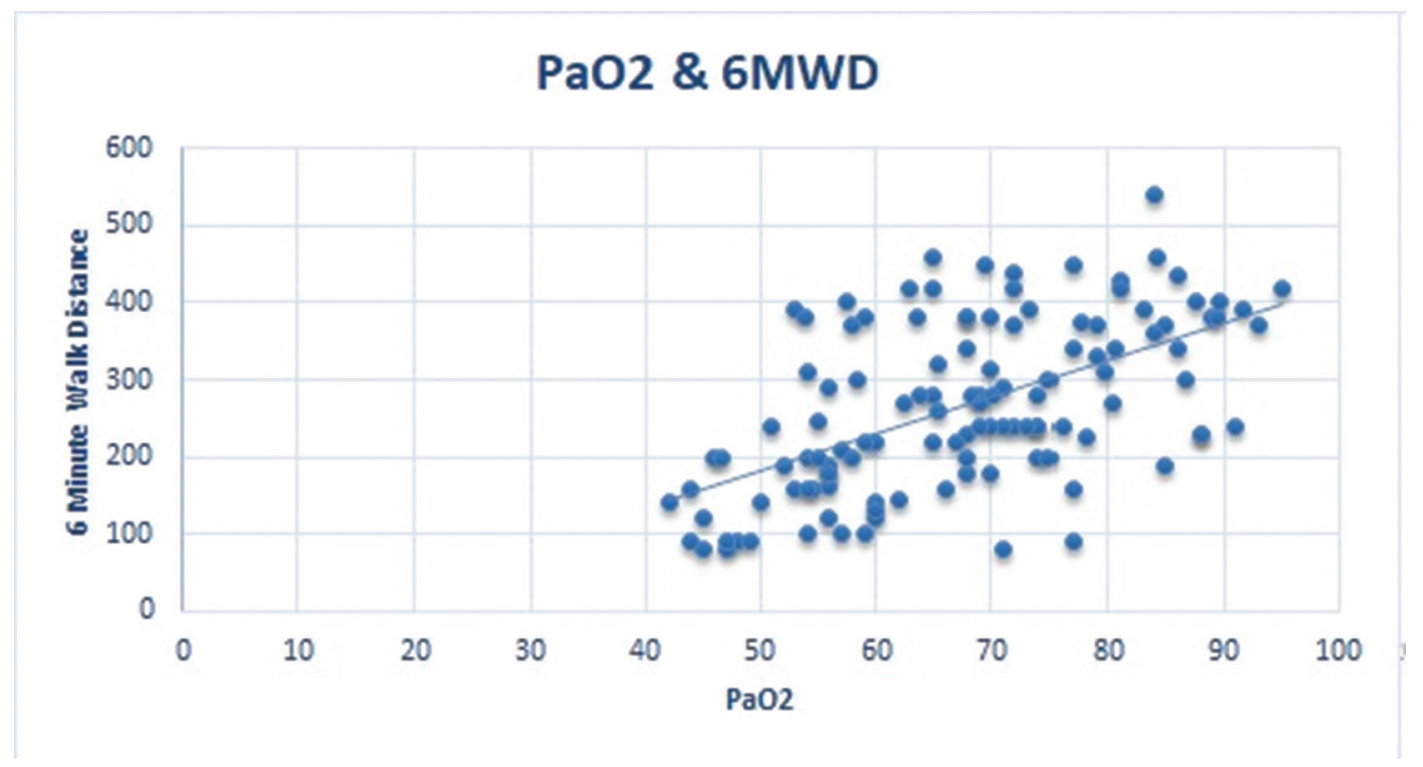

Figure 3. Correlation between $6 \mathrm{MWD}$ and $\mathrm{PaO}_{2}$. $\mathrm{MWD}$, minute walk distance.

represented both the short form and the abbreviated name of our institute. The TNMC-GAP results when compared with GAP were compared using the paired $t$ test and there was concordance in our results, as the difference in mortality predicted by ILD-GAP and the TNMC-ILD-GAP models was statistically insignificant $(P>0.050)$. In the study conducted by Ryerson et al, diagnosis of CTD-ILD versus idiopathic NSIP did not carry independent prognostic significance when adjusting for the ILD-GAP model. Hence the two were clubbed together, and mortality rates were seen to be similar within the group. However, in our study, it was seen than CTD-related ILD has much better prognosis, and a lower mortality than all the other types of ILDs.

Lower 6 MWD, hypoxia, pulmonary hypertension, severe restriction and cardiac comorbidities are all seen to have a negative impact on prognosis, as seen in different studies (20-23). In our patients, age, male gender, DLCO $<35$, severe restriction and low 6 MWD significantly affected survival. While moderate to severe pulmonary hypertension, $\mathrm{PaO}_{2}<60 \mathrm{mmHg}$, and cardiac comorbidities were present in a large number of patients, these were not significant in our cohort as far as mortality was concerned. One of the major limitations of our study was a relatively smaller sample size, because of which a reverse Kaplan-Meir survival analysis was not possible. Hopefully, in the future, the same index can be applied and studied in a larger sample.

To summarise, we propose that the ILD-GAP model may be replaced with the TNMC-ILD-GAP model in resource limited settings, as 6 MWD is a good predictor of mortality. This has been seen in many studies, including ours. However, more studies are needed to validate our findings, including the favourable prognosis of CTD-associated ILD.

\section{Author contributions}

Conceptualisation of the work was done by J.M. Joshi and Unnati Desai. Formal analysis, software, validation, investigation, original draft, and preparation and writing were executed by Sameer Bansal and Unnati Desai. Methodology, data curation, review and editing, and approval and writing of the final manuscript were done by all the authors.

\section{References}

1. Ryerson C, Vittinghoff E, Ley B, Lee J, Mooney J, Jones K, et al. Predicting survival across chronic interstitial lung disease. Chest. 2014;145: 723-728.

2. Park JH, Kim DS, Park I-N, Jang SJ, Kitaichi M, Nicholson AG, et al. Prognosis of fibrotic interstitial pneumonia. American Journal of Respiratory and Critical Care Medicine. 2007;175: 705-711.

3. Ley B, Ryerson CJ, Vittinghoff E, Ryu JH, Tomassetti S, Lee JS, et al. A multidimensional index and staging system for idiopathic pulmonary fibrosis. Annals of Internal Medicine. 2012;156: 684-691.

4. Mura M, Porretta MA, Bargagli E, Sergiacomi G, Zompatori M, Sverzellati $\mathrm{N}$, et al. Predicting survival in newly diagnosed idiopathic pulmonary fibrosis: a 3-year prospective study. European Respiratory Journal. 2012;40: 101-109. 
5. Bois RMD, Weycker D, Albera C, Bradford WZ, Costabel U, Kartashov A, et al. Ascertainment of individual risk of mortality for patients with idiopathic pulmonary fibrosis. American Journal of Respiratory and Critical Care Medicine. 2011;184: 459-466.

6. Miyamoto S, Nagaya N, Satoh T, Kyotani S, Sakamaki F, Fujita $\mathrm{M}$, et al. Clinical correlates and prognostic significance of sixminute walk test in patients with primary pulmonary hypertension. American Journal of Respiratory and Critical Care Medicine 2000;161: 487-492.

7. Caminati A, Bianchi A, Cassandro R, Mirenda MR, Harari S. Walking distance on 6-MWT is a prognostic factor in idiopathic pulmonary fibrosis. Respiratory Medicine. 2009;103: 117-123.

8. Celli BR, Cote CG, Marin JM, Casanova C, MM de Oca, Mendez RA, et al. The body-mass index, airflow obstruction, dyspnea, and exercise capacity index in chronic obstructive pulmonary disease. The New England Journal of Medicine. 2004;350: 1005-1012.

9. Travis WD, Costabel U, Hansell DM, King TE, Lynch DA, Nicholson AG, et al. An official american thoracic society/ european respiratory society statement: update of the international multidisciplinary classification of the idiopathic interstitial pneumonias. American Journal of Respiratory and Critical Care Medicine. 2013;188: 733-748.

10. Bendstrup E, Maher T, Manali E, Wijsenbeek M. Challenges in the classification of fibrotic ILD. Sarcoidosis Vasculitis and Diffuse Lung Disease 2015;32(Suppl 1): 4-9.

11. Martinez FJ, Safrin S, Weycker D, Starko KM, Bradford WZ, King TE Jr., et al; IPF Study Group. The clinical course of patients with idiopathic pulmonary fibrosis. Annals of Internal Medicine. 2005;142: 963-967.

12. Global Initiative for Asthma. Global strategy for asthma management and prevention. Updated 2021. Available from: https://ginasthma.org/wp-content/uploads/2021/05/GINA-MainReport-2021-V2-WMS.pdf.

13. Global Initiative for Chronic Obstructive Lung Disease (GOLD). Global strategy for the diagnosis, management and prevention of COPD. Updated 2021. Available from: https://goldcopd. org/wp-content/uploads/2020/11/GOLD-REPORT-2021-v1.125Nov20_WMV.pdf.
14. Goldstraw P, Crowley J, Chansky K, Giroux DJ, Groome PA, Rami-Porta R, et al; International Association for the Study of Lung Cancer International Staging Committee. The IASLC lung cancer staging project: proposals for the revision of the TNM stage groupings in the forthcoming (seventh) edition of the TNM classification of malignant tumours. Journal of Thoracic Oncology. 2007;2: 706-714.

15. Low S. Using the ILD-GAP model to predict mortality in chronic interstitial lung disease. European Respiratory Journal. 2015;46(Suppl 59): PA3824. doi: 10.1183/13993003.congress-2015.PA3824.

16. Ley B, Collard HR, TE King Jr. Clinical course and prediction of survival in idiopathic pulmonary fibrosis. American Journal of Respiratory and Critical Care Medicine, 2011;183: 431-440.

17. American Thoracic Society. Single-breath carbon monoxide diffusing capacity (transfer factor): recommendations for a standard technique-1995 update. American Journal of Respiratory and Critical Care Medicine. 1995;152: 2185-2198.

18. Jensen RL, Carpo RO. Diffusion capacity: how to get it right. Respiratory Care. 2003;48: 777-782.

19. Lederer DJ, Arcasoy SM, Wilt JS, D'ovidio F, Sonett JR, Kawut SM. Six-minute-walk distance predicts waiting list survival in idiopathic pulmonary fibrosis. American Journal of Respiratory and Critical Care Medicine. 2006;174: 659-664.

20. Nathan SD, Basavaraj A, Reichner C, Shlobin OA, Ahmad S, Kiernan J, et al. Prevalence and impact of coronary artery disease in idiopathic pulmonary fibrosis. Respiratory Medicine. 2010;104: 1035-1041.

21. Behr J, Ryu J. Pulmonary hypertension in interstitial lung disease. European Respiratory Journal. 2008;31: 1357-1367.

22. Corte TJ, Wort SJ, Talbot S, Macdonald PM, Hansell DM, Polkey M. et al. Elevated nocturnal desaturation index predicts mortality in interstitial lung disease. Sarcoidosis Vasculitis and Diffuse Lung Diseases. 2012;29: 41-50.

23. du Bois R, Albera C, Bradford W, Costabel U, Leff J, Noble P, et al. 6-minute walk distance is an independent predictor of mortality in patients with idiopathic pulmonary fibrosis. European Respiratory Journal. 2013;43: 1421-1429. 